\title{
Incomplete understanding of biogas chemical hazards - Serious gas poisoning accident while unloading food waste at biogas plant
}

\section{Hedlund, Frank Huess; Madsen, Michael}

Published in:

Journal of Chemical Health and Safety

Link to article, DOI:

10.1016/j.jchas.2018.05.004

Publication date:

2018

Document Version

Early version, also known as pre-print

Link back to DTU Orbit

Citation $(A P A)$ :

Hedlund, F. H., \& Madsen, M. (2018). Incomplete understanding of biogas chemical hazards - Serious gas poisoning accident while unloading food waste at biogas plant. Journal of Chemical Health and Safety, 25(6), 13-21. https://doi.org/10.1016/j.jchas.2018.05.004

\section{General rights}

Copyright and moral rights for the publications made accessible in the public portal are retained by the authors and/or other copyright owners and it is a condition of accessing publications that users recognise and abide by the legal requirements associated with these rights.

- Users may download and print one copy of any publication from the public portal for the purpose of private study or research.

- You may not further distribute the material or use it for any profit-making activity or commercial gain

- You may freely distribute the URL identifying the publication in the public portal 


\section{Incomplete understanding of biogas chemical hazards - Serious gas poisoning accident while unloading food waste at biogas plant}

Frank Huess HEDLUND ${ }^{a, b}{ }^{*}$, Michael MADSEN ${ }^{c}$

${ }^{a}$ COWI; Parallelvej 2, DK-2800 Kongens Lyngby, Denmark, E-mail: fhhe@cowi.com

b Technical University of Denmark, (DTU/Compute) DK-2800 Kongens Lyngby, Denmark. E-mail: fhuhe@,dtu.dk

${ }^{c}$ Ramsherred 37 C, DK-6200 Aabenraa, Denmark, E-mail: michael.madsen@maskau.dk

* Corresponding author

This is a pre-print of

Hedlund, F. H., and Madsen, M., Incomplete understanding of biogas chemical hazards - Serious gas poisoning accident while unloading food waste at biogas plant. J. Chem. Health Safety (2018), https://doi.org/10.1016/j.jchas.2018.05.004 


\section{Abstract}

At a biogas plant, a truck driver was overcome by toxic fumes while unloading food waste slurry collected at sites that operate a shredder and tank system. Trucks unload their cargo into a feedstock pit. While unloading, hydrogen sulfide, carbon dioxide and possibly other toxic gases were released. Ventilation systems were overwhelmed. The driver narrowly escaped death. Several would-be rescuers collapsed. Under marginally different conditions, this accident could have led to five fatalities.

The case offers a rich account of the actions of fellow workers who with stubborn determination sought to extract the unconscious driver. Even after having collapsed themselves, been extracted and recovered, they re-entered the building - amazingly still without realizing the gas danger.

The article argues that long retention time in the logistics chain may alter the hazard profile of food waste slurry. This emerging risk appears overlooked and under-studied.

The case exposes insufficient attention to safety in the rapidly expanding biogas sector. The biogas plant was unprepared. The investigation was quick, superficial and woefully inadequate. Root causes were not identified. Broad information sharing is limited or non-existent. 


\section{Table of Contents}

1 Introduction 4

1.1 The policy context of biogas from food waste 4

1.2 Food waste recycling systems 4

1.3 Biogas risks 5

2 Material and methods 6

$3 \quad$ The Hashøj biogas plant $\quad 7$

$\begin{array}{lll}3.1 & \text { Plant overview } & 7\end{array}$

$\begin{array}{lll}3.2 & \text { The feedstock reception building } & 7\end{array}$

$\begin{array}{lll}3.3 & \text { The feedstock pit tank } & 7\end{array}$

$4 \quad$ The gas poisoning accident 10

4.1 The accident food waste 10

4.2 Feedstock pit composition prior to food waste offloading 10

$\begin{array}{lll}4.3 & \text { Driver overcome by fumes } & 11\end{array}$

4.4 Would-be rescuers overcome by gases 11

4.5 Paramedics enter the building 12

$\begin{array}{lll}4.6 & \text { Arrival of fire and rescue services } & 12\end{array}$

$\begin{array}{lll}4.7 & 13\end{array}$

$\begin{array}{lll}4.8 \text { Aftermath } & 13\end{array}$

5 Discussion $\quad 14$

5.1 Evidence for hydrogen sulfide poisoning 14

5.2 Evidence for carbon dioxide poisoning 14

$\begin{array}{lll}5.3 & \text { No evidence for presence of } \mathrm{NO}_{\mathrm{x}} & 15\end{array}$

$\begin{array}{lll}5.4 & \text { Food waste as a source of } \mathrm{H}_{2} \mathrm{~S} & 15\end{array}$

5.5 Hypothesis: Disturbed pit 15

5.6 Hypothesis: Displacement gases 16

5.7 Best hypothesis: Unusually high contents of $\mathrm{H}_{2} \mathrm{~S}$ in the $20 \mathrm{~m}^{3}$ batch of food waste

5.8 Other hydrogen sulfide biogas accidents, a comparative view 16

$\begin{array}{ll}5.9 \text { Limited information available } & 17\end{array}$

$\begin{array}{ll}5.10 \quad \text { Limited information sharing } & 17\end{array}$

$\begin{array}{ll}5.11 \quad \text { Limited sustainability } & 17\end{array}$ 
$7 \quad$ Conflicts of interest

8 Acknowledgements

$9 \quad$ References

23 


\section{Introduction}

\subsection{The policy context of biogas from food waste}

Biogas, mainly methane and carbon dioxide, is produced by anaerobic microbial degradation of organic material. The International Gas Union considers renewable energy production in the form of biogas an efficient way to satisfy multiple EU policy expectations and biogas has become Europe's fastest growing renewable energy sector [1]. A Danish political agreement in 2009, stipulates a tenfold increase in the amount of livestock manure treated by biogas plants: from $5 \%$ in 2007 to an astonishing $50 \%$ by year 2020 [2]. Subsidies available to biogas producers have increased [3].

One of the problems facing the biogas sector is limited availability of suitable energy-rich cosubstrates, since livestock manure has a too low biogas potential (too low energy density) to be economically feasible. The use of edible crops or energy crops as co-substrates is discouraged because of ethical issues and sustainability concerns.

It is politically more appealing to recycle biodegradable waste streams that would otherwise go to a waste incineration facility. Food waste is an attractive candidate - the waste stream becomes an energy resource, substituting fossil fuels, and the digestate can be recycled to farmland, closing material and nutrient loops in accordance with ideas from industrial ecology and the more recent conceptions of a circular economy.

The most recent (2017) Danish resource strategy calls for a fourfold increase in recycling of food waste from 2011 to 2018 [4,5].

\subsection{Food waste recycling systems}

Several vendors offer proprietary food waste recycling systems. A system comprises a shredder, a holding tank and connecting pipework. The shredder adds sufficient water to produce a food waste slurry, which is pumped to a so-called biotank elsewhere on the premises.

Once in the biotank, the slurry is said to become dormant. No chemicals or preservatives are added so the vendors may refer to microbial acidification. The acidification does not irreversibly inactivate microorganisms in the slurry. Still, acidification may stabilize it, as most microorganisms require $\mathrm{pH}$ values above, say, 5.0 to grow.

Some vendors offer service agreements, monitoring the biotank's filling level and arranging for a vacuum truck to haul the slurry to a biogas plant. The vendor issues yearly environmental performance statements that detail e.g. the quantity of food waste recycled, biogas produced and $\mathrm{CO}_{2}$ emissions saved for use in the food waste producer's green accounting reporting practices. 
Vendors also emphasize improved kitchen hygiene, less manual handling of heavy food waste, and elimination of the bulky and charmless food waste bins. This is welcome in the catering sector where musculoskeletal disorders are prevalent. The systems also rationalize food waste logistics. A Danish hospital reported that food waste collection now takes place only 8-10 times a year, down from 150 times a year. Obvious benefits include lower transportation costs and less nuisance noise.

Vendors state (personal communication) that biotanks typically are emptied every 3-5 weeks. Sitespecific constraints, however, such as spare floor space and the size of access door openings often determine the biotank's size and the site's storage capacity. Food waste collection frequency can vary considerably amongst sites.

This article argues, 1) that the long retention time in the transportation chain may alter the properties of the food waste slurry due to physical, chemical or microbial degradation processes, 2) possibly changing its hazard profile, and 3) that this possibility appears overlooked and under-studied. There seems to be little incentive in industry to study this topic. Food waste is not classified as hazardous.

\subsection{Biogas risks}

As if by industry convention, dry biogas is said to comprise about 65 vol- $\%$ methane, 35 vol- $\%$ carbon dioxide and a number of trace gases such as hydrogen sulfide, ammonia, nitrous oxide and hydrogen chloride [6]. Biogas composition varies considerably however, since substrate composition as well as operational parameters influence the gas composition.

Biogas entails three major risks: explosion risk due to the methane content, toxicity risk due to the presence of hydrogen sulfide and other gases, and microbial risk due to the presence of pathogens. Frequently cited papers on anaerobic digestion as a method to generate energy from food waste, e.g. $[7,8]$, are silent on workplace risks. Only few biogas accident case stories $[9,10]$ are shared in the literature. Some authors argue however, that biogas production presents significant emerging risks $[11,12]$ and that the number of accidents is growing faster than the amount of energy produced [13]. 


\section{Material and methods}

Interviews were conducted with everybody present the morning of the gas release, fire and rescue personnel excluded. Follow-up interviews were conducted to reconcile conflicting accounts and reconstruct the most probable waste composition, pit composition and timeline. Arrivals were crosschecked with video camera time stamps. Feedstock pit level readings were retrieved from plant PLC printouts. A site visit took place Oct 15, 2015.

Other primary sources are dockets of the Danish Working Environment Authority, the Municipal Environmental Authority and the Police obtained through the Danish equivalent of a Freedom of Information Act. 


\section{The Hashøj biogas plant}

\subsection{Plant overview}

The Hashøj Biogas plant was commissioned in 1994 to supply gas to a combined heat and power station in the town of Dalmose some $2 \mathrm{~km}$ away. In 2015, main plant components comprised a feedstock reception building, homogenizer, pasteurizers, digesters, biofilters, double membrane gas storage holders and substrate holding tanks (Figure 1).

\subsection{The feedstock reception building}

For odor emission control, the feedstock pit is located inside a building with a general exhaust ventilation system. The building has three steel roll shutter gates, two in the side walls, one in the gable wall. Gates are normally closed. Regular access doors are installed next to the gates.

\subsection{The feedstock pit tank}

Trucks use the \#2 gate in the gable wall, reverse in and dump the cargo into in the feedstock pit (Figure 2). The pit has an actuated lid and continuous local exhaust ventilation. Road tankers use the side wall gates \#1 and \#3 and unload manure into the pit via a feed chute (Figure 3 ). The chute also has continuous local exhaust ventilation. 


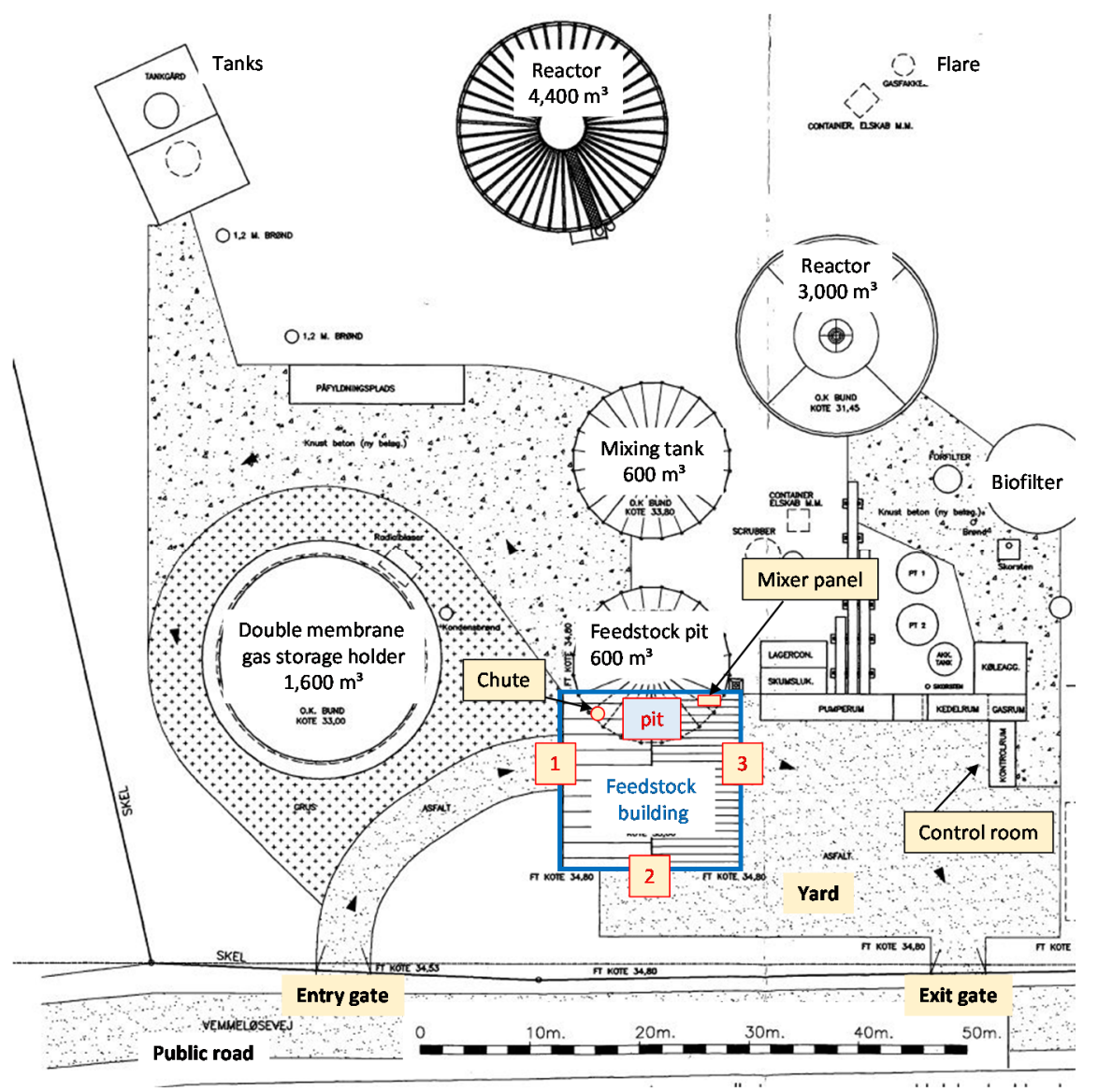

Figure $1 \quad$ The Hashøj biogas plant with feedstock reception building and steel roll shutter gates \#1 and \#3 in the side walls and \#2 in the gable wall. The plant has since expanded with an additional gas storage holder (not shown). Source: Building permit dated Sept. 2003. 


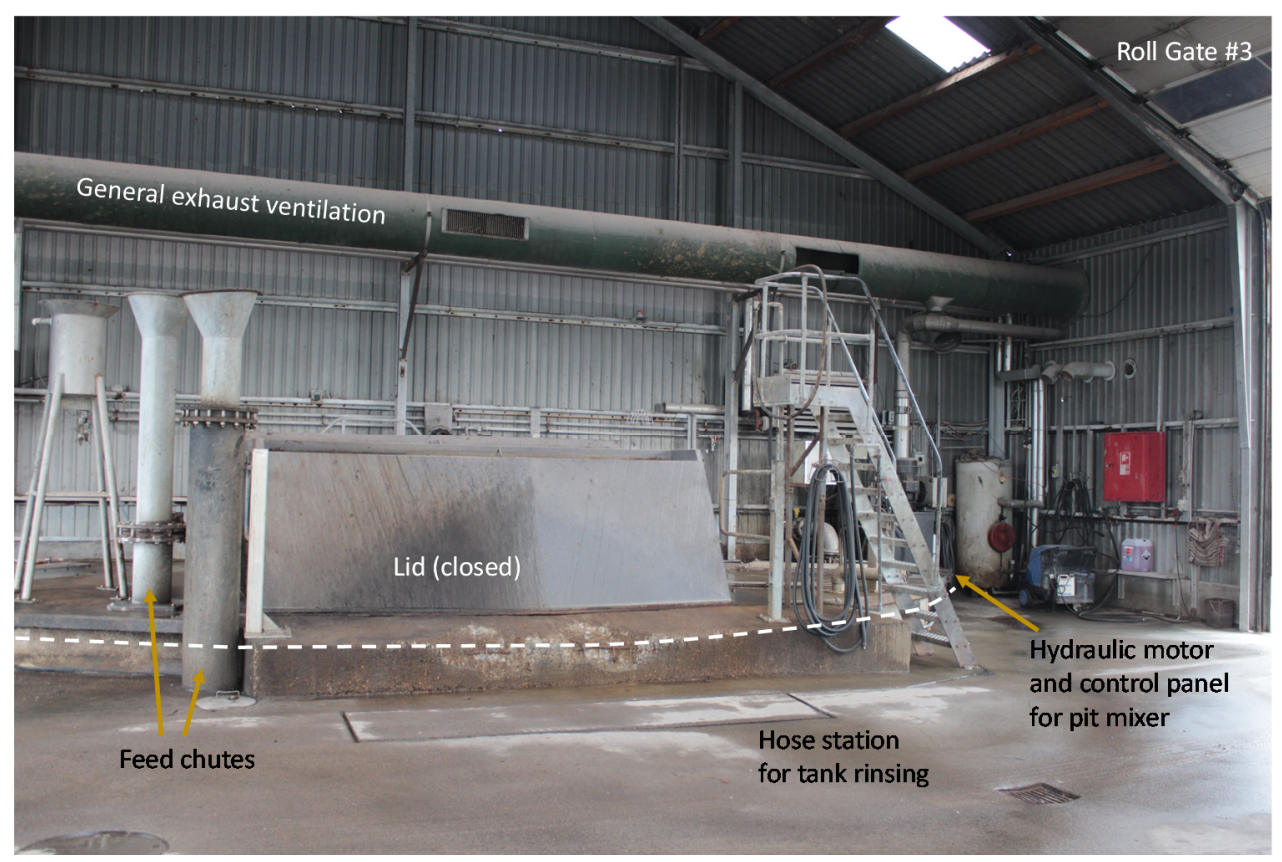

Figure 2 The feedstock pit with the lid closed. Feed chutes are at centre left.. Dotted line shows pit tank contour (Photo: Frank Hedlund)

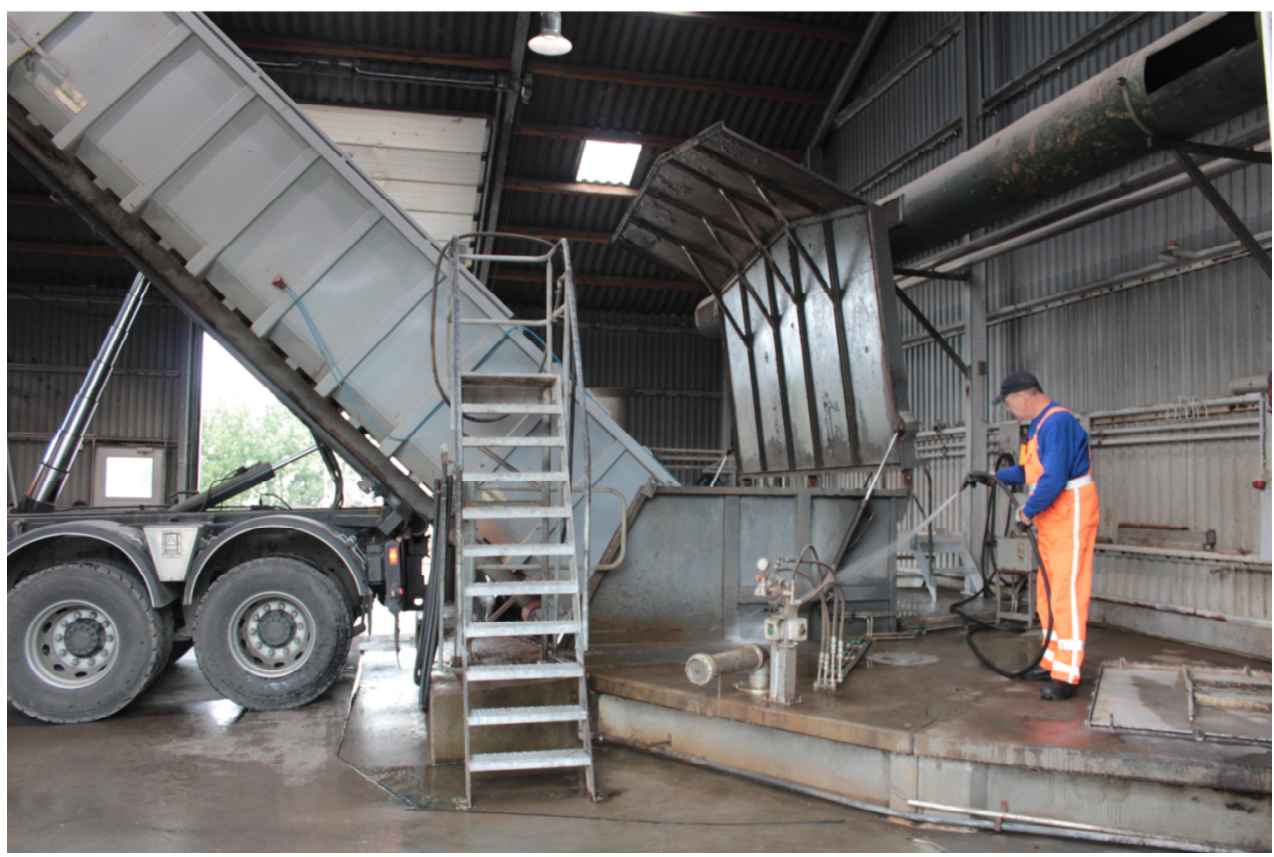

Figure 3 A container tank is hosed down after having unloaded pork abattoir offal (intestines) into the feedstock pit. Note the open lid. (Photo: Frank Hedlund) 


\section{$4 \quad$ The gas poisoning accident}

\subsection{The accident food waste}

The accident truck driver is the owner of a small family-run business specializing in sanitary sewer cleaning services. The company has expanded into food waste collection.

Minimizing transportation costs is essential to make the food waste business profitable. The nearest biogas plant (Hashøj) is about $100 \mathrm{~km}$ away. Food waste is therefore temporarily kept at company premises in two dedicated roll-off container tanks, capacity $20 \mathrm{~m}^{3}$ and $15 \mathrm{~m}^{3}$. The largest tank is filled first. The average retention time appears to be about 6-8 weeks. Off-gasses, if any, are vented to the open air.

Likely, the oldest batches of the accident food waste slurry (in the $20 \mathrm{~m}^{3}$ tank) had been stored for perhaps three months before arriving at the biogas plant. June and July 2015 were colder than normal with average daily temperatures of about $13{ }^{\circ} \mathrm{C}$ and $16{ }^{\circ} \mathrm{C}$ respectively. Early July saw heat waves with maximum temperatures exceeding $30^{\circ} \mathrm{C}$. The owner (and accident driver) has informed that handling and intermediate storage of the accident food waste in the container tanks was uneventful with no observation of nuisance odors or other anomalies.

The accident food waste had been collected at several food waste producers over time, likely hospital kitchens.

\subsection{Feedstock pit composition prior to food waste offloading}

At the time of the accident, the main constituent in the feedstock pit was hog manure.

The last truckload received the previous day was pork abattoir waste, mostly intestines. The crew also emptied a 1,000 liter IBC tank with discarded wine gum, a waste product from a candy maker, into the pit. This is done just before closing time, as it gives rise to a distinctly repulsive stench. At the end of the working day, when the stirrer was turned off, the pit level was at 47 percent, $282 \mathrm{~m}^{3}$.

Early next morning, on August 6, 2015, a road tanker delivered three loads of hog manure, at 04:40, 05:21 and 05:59, each of $34 \mathrm{~m}^{3}$. The driver entered gate $\# 1$ and used the feed chute, not the pit. Each unloading operation took about 8 minutes. The driver has no recollection of foul air or other anomalies. 


\subsection{Driver overcome by fumes}

The accident truck driver (driver A) arrives at the main gate at 06:25. He is alone at the site. He reverses the truck and trailer through gate \#2. Other gates are closed. He approaches the feedstock pit six times. The lid actuation control panel (1) is located besides the pit. The rear end of the container tank features a 4" quick release discharge valve. He leans over the open pit (2) to reach the handle and open the valve.

Unloading takes 8-10 minutes. In the meantime, he dons his boiler suit, which he keeps in a small compartment located next to the door of the driver's cabin. The truck and trailer is longer than the building and the driver's cabin is in the open air. The container tank's rear end gate is top-hinged, gasketed and compression sealed with a wing screw at both sides. When unloading is complete, the driver releases both wing screws $(3,4)$, each time standing next to the open pit. He flushes out the container using a water hose, standing behind the pit (5), see also Figure 3. The trailer unloading is uneventful. The driver has no recollection of foul air or other anomalies.

He walks back to the driver's cabin, undons the boiler suit and drives out, likely at 06:44. According to the biogas plant's operating procedures, he should return to the pit and close the lid (6). To save time, he leaves the lid open. Outside, he parks the trailer and disconnects the various pneumatic and hydraulic hoses. At about 06:45 the Plant Supervisor arrives. He briefly enters the building, turns on the pit stirrer and leaves for the office building. The Plant Supervisor notices nothing unusual, no foul odors.

The driver reverses the truck into the building at 06:49. With the lid open, he can reverse all the way to the pit. He opens the rear discharge valve and starts unloading $20 \mathrm{~m}^{3}$ of food waste. He walks towards the driver's cabin, which is now inside the building, to fetch his boiler suit. He has no memory of what happens next.

Truck driver B arrives at 06:51. He enters the open gate \#2, probably at 06:52, and remembers a "very strong smell" and a stinging sensation in the eyes. He is the only witness reporting foul odors inside the building. Driver A is standing next to the driver's cabin holding his boiler suit. They have not met before but have a friendly chat for a couple of minutes.

They slowly walk towards gate \#2. Driver B leaves the building, probably at $06: 56$, and Driver A walks down the truck's right side to release the rear wing screw. Outside, Driver B hears strange sounds and turns around. He sees Driver A reeling past the trucks's front, on his way to release the rear wing screw on the left side, then collapsing next to the driver's cabin, probably at 06:57

\subsection{Would-be rescuers overcome by gases}

Driver B rushes inside to help. Driver A has vomited and has urinated in his pants. Driver B attempts to turn him face down to prevent him suffocate on his own vomit but Driver A is too heavy.

While outside, Driver B noticed the Carpenter arriving at the gate. The Carpenter is working on a laboratory shed inside the building. Driver B asks the Carpenter for help. They cannot turn Driver A around, whose skin is now turning blue. They suspect a heart attack. The Carpenter has no recollection of any smell, but remembers a strong urge to urinate.

The Carpenter runs to the office to have the supervisor come assist. Driver B calls the alarm number 112 using his cell phone. Because of the noise from the hydraulic power station that powers the pit 
stirrer, he leaves the building to make the call. While leaving the office, the Carpenter and the Plant Supervisor meet the Plant Manager, who has just arrived at 06:59. Already at the main gate, which is upwind the pit building, the Plant Manager noticed a very bad sulfur-like stench. He is the only witness to report a foul odor outside the building.

All three enter the building, probably at 07:01. Driver B stays outside to keep contact with 112 . Believing it is a heart attack, the operator at 112 instructs them to stay with the unconscious driver and report his condition. The Plant Supervisor suddenly feels ill and wants to get out, immediately. He reels towards the open gate \#2, probably at 07:03. Outside, he recovers, short of breath, as if having "run a marathon". The Plant Manager, still inside, shouts something to him, but his breathing is too labored for him to respond.

The Carpenter and the Plant Manager attend the unconscious driver. The Carpenter suddenly fells an overwhelming urge to urinate. He rushes out gate \#2, probably at 07:03, and remembers being extremely short of breath, as if having "run a $100 \mathrm{~m}$ sprint". He attempts to urinate but realizes that he has already urinated in his pants. He remembers blaming himself intensely for not having "what it takes" to respond in an emergency situation. He re-enters the building, probably at 07:04. There, he finds the Plant Manager crouching down, knees in armpits, sitting upright on some construction materials for the shed. The Plant Manager is unconscious, eyes wide-open and red, mouth frothing and having urinated in his pants. The Carpenter has a vague recollection, as if someone dragged a black curtain over him. He passes out. There are now three unconscious persons inside the building.

Outside, the Plant Supervisor has recovered. He opens the door next to gate \#3, probably at 07:05, and sees the Plant Manager sitting, and the Carpenter wobbling around, losing his balance, attempting to crawl on hands and knees, then collapsing. The Plant Supervisor insists it simply did not occur to him, that toxic gases could be present. He has utmost respect for gases. Some year ago, at a previous employer, a colleague died inside a road tanker while cleaning it, because it had been flushed with nitrogen. He cannot explain why but decides to open gate \#3 and \#1, a fortuitous move. He then drags the Carpenter outside, probably at 07:06.

The Carpenter recovers rather quickly. Together, they re-enter the building and drag the Plant Manager outside, probably at 07:09, who recovers slowly. The first ambulance arrives at the gate at 07:12.

\subsection{Paramedics enter the building}

The paramedics ask the Plant Supervisor and the Carpenter if there is a gas danger inside the building. The answer is negative, "because they had just been in there" (!), dragging people out. The paramedics ask the Carpenter to help pull the unconscious driver onto a stretcher and together they enter the building. The operation is successful and the unconscious driver is immediately (probably at 07:14) administered oxygen and CPR and later rushed to hospital where he was put in an artificial coma.

\subsection{Arrival of fire and rescue services}

The fire and rescue services arrive shortly after. They take gas measurements at 07:44: VOC (volatile organic compounds): 0 ppm; LEL (flammable gases): 0 ppm; $\mathrm{NO}_{\mathrm{X}}: 12$ ppm; Oxygen: 20,7 $\%$-vol; $\mathrm{CO}_{2}$ : 0 ppm; and $\mathrm{H}_{2} \mathrm{~S}: 0$ ppm. 
The (misleading) presence of fumes of nitrous oxides $(\mathrm{NO} \times)$ is communicated to the medical staff at the Emergency Room, the Police, government agencies, and the press.

\subsection{Investigation}

Two inspectors from the workplace authority made a site visit the same day and issued several orders, inter alia to increase the capacity of the exhaust ventilation systems, install gas detectors and make gas masks available. There was no data collection and no attempt to try understand the circumstances.

The media reported that a truck driver had been overcome by nitrous oxide fumes at a biogas plant. The police carried out a crime scene investigation and collected witness statements. They found no evidence of wrongdoing and closed the case.

The environmental authority had samples of the food waste analyzed for nitrous oxides, took pictures of the accident scene, and prepared a short report. The laboratory later reported the samples had a $\mathrm{pH}$ of 3.2, an oxygen content of $1.7 \mathrm{mg} / \mathrm{l}$, and a very low nitrite/nitrate content of only $0.04 \mathrm{mg} / \mathrm{l}$.

\subsection{Aftermath}

Everybody has recovered and has returned to work. We don't know, if Driver A has recovered entirely without sequelae. 


\section{Discussion}

\subsection{Evidence for hydrogen sulfide poisoning}

Hydrogen sulfide is a colorless, poisonous, flammable and irritant gas with a strong odor of rotten eggs. The toxicity of $\mathrm{H}_{2} \mathrm{~S}$ is similar to that of cyanide [14]. The exposure-response relationship for acute effects can be very steep. Cases involving over-exposure have documented a variety of symptoms, such as dizziness, nausea, abrupt collapse or knockdown [15]. Death from acute poisoning results usually from failure of respiration [16]. Lower levels have been associated with eye, nose, and throat irritation $[15,17]$.

In theory, $\mathrm{H}_{2} \mathrm{~S}$ has excellent warning properties - the odor threshold may be as low as $3 \mathrm{ppb}$ to 20 $\mathrm{ppb}$ [15]. Higher concentrations quickly lead to olfactory paralysis however. The danger in high concentrations is therefore easily underestimated. Because $\mathrm{H}_{2} \mathrm{~S}$ in small quantities is common at biogas plants, we argue that staff may become accustomed and de-sensitized to the foul smell of the gas, which nullify the warning properties of the low odor threshold.

The case presents evidence consistent with hydrogen sulfide poisoning such as irritation of the eyes, mouth frothing, vomit, knock-down and unconsciousness.

Remarkably, only two witnesses reported a foul odor. This is consistent with observations from earlier hydrogen sulfide accidents however. In a previous accident where two chemicals reacted in the sewer system of a chemical plant and released large amounts of $\mathrm{H}_{2} \mathrm{~S}$ gas, only two of ten severely affected but surviving individuals stated that they smelled the putrid odor of hydrogen sulfide [16]. At a major $\mathrm{H}_{2} \mathrm{~S}$ release from a monoethanolamine (MEA) Girbotol sulfur recovery plant in Mexico, which killed 22 persons, only one of 47 hospitalized patients noticed the odor of rotten eggs [17].

\subsection{Evidence for carbon dioxide poisoning}

Carbon dioxide is an odorless and colorless heavy gas. Although it is often considered a nontoxic asphyxiant gas that can displace the oxygen required to sustain life, it has significant physiological effects which will be experienced before effects of oxygen deprivation set in [18]. One such effect is increased respiration. At 10 vol-\% severe symptoms of labored breathing make normal speech difficult or impossible. Unconsciousness occurs after one to several minutes exposure to 10-15 vol$\%$. Above 15\%-vol, loss of consciousness occurs in less than one minute [18].

The Hashøj case presents evidence consistent with carbon dioxide toxicity, in particular the Plant Supervisor experiencing severe shortness of breath, as if having "run a marathon" and his breathing was too labored for him to speak. The Carpenter also reported being extremely short of breath. 
We remark that increased respiration can produce synergistic effects, increasing the exposure to other toxic inhalation gases present.

\subsection{No evidence for presence of $\mathrm{NO}_{x}$}

The most hazardous of the nitrogen oxides are nitric oxide $(\mathrm{NO})$ and nitrogen dioxide $\left(\mathrm{NO}_{2}\right)$. Nitrogen dioxide is a reddish-brown heavy gas that has a sharp, harsh odor at higher concentrations, but may be clear and odorless at lower, but still harmful, concentrations. The gas is poorly soluble in water and can penetrate deep into the lower respiratory tract where it can cause life-threatening pulmonary edema [19-21].

Cases of harmful exposures are often initially associated with mild symptoms of respiratory irritation, which subside upon termination of exposure, or may even be asymptomatic, with fatal complications (lung edema) developing hours later [22]. Latency periods may be in the range from 3 to 30 hours $[19,23]$.

The Hashøj case offers no evidence for the presence of nitrous oxides in harmful concentrations. Assuming that invisible $\mathrm{NO}_{\mathrm{X}}$ fumes were present in low to moderate concentrations, knock-down is an unlikely effect.

We speculate that engine exhaust gases were the source of the $\mathrm{NO}_{\mathrm{X}}$ readings.

\subsection{Food waste as a source of $\mathrm{H}_{2} \mathrm{~S}$}

The concentration of $\mathrm{H}_{2} \mathrm{~S}$ in biogas is variable and depends on the substrate. The subject does not appear to be extensively studied. Sewage sludge is reported to produce little $\mathrm{H}_{2} \mathrm{~S}$, less than $10 \mathrm{ppm}$, hog manure 1,200-2,400 ppm, and food waste even higher concentrations, in the range 500-6,000 ppm [6].

We speculate that catering waste from hospital kitchens likely contains much residual protein. The sulfur-containing amino acids in proteins are broken down during hydrolysis and acidogenesis and are ultimately potentially transformed to, among other things, hydrogen sulfide. Sulfate present in the waste might be converted to $\mathrm{H}_{2} \mathrm{~S}$ by sulfate reducing bacteria $[24,25]$.

We conclude that food waste is a credible candidate for producing $\mathrm{H}_{2} \mathrm{~S}$ in high concentrations.

\subsection{Hypothesis: Disturbed pit}

Due to the higher density than air, released $\mathrm{H}_{2} \mathrm{~S}$ can accumulate on the surface of un-disturbed manure in pits. The greatest $\mathrm{H}_{2} \mathrm{~S}$ danger is present during agitation and pumping of the pit content [14].

This hypothesis cannot explain that Driver A did not observe foul air when re-entering the building when unloading the second batch, whereas Driver B did so when entering shortly after. Additionally, that the three loads of hog manure and the first load of food waste would also disturb the pit. 


\subsection{Hypothesis: Displacement gases}

Another hypothesis is that displacement gases from the pit during unloading would release dangerous gases from the pit. For many of the same reasons as above (disturbed pit), the hypothesis is weak.

\subsection{Best hypothesis: Unusually high contents of $\mathrm{H}_{2} \mathrm{~S}$ in the $20 \mathrm{~m}^{3}$ batch of food waste}

We hypothesize that unexplained microbial activity or chemical degradation had created unusually large quantities of $\mathrm{H}_{2} \mathrm{~S}$ in this batch. The $\mathrm{pH}$ of the batch was rather low, measured at 3.2. $\mathrm{H}_{2} \mathrm{~S}$ may have degassed from this food waste when released from the rear nozzle of the container tank.

We believe that rapid release of $\mathrm{H}_{2} \mathrm{~S}$ instantly lead to olfactory paralysis of Driver A when he opened the nozzle. A few minutes later, gases had filled the building, which Driver B experienced as foul air and a stinging sensation in the eyes upon entering the building. When Driver A approached the pit to release the first wing screw, he was exposed to very high concentrations that shortly after made him collapse.

We cannot offer a good mechanism for the observed evidence of $\mathrm{CO}_{2}$ poisoning.

\subsection{Other hydrogen sulfide biogas accidents, a comparative view}

Early morning on Nov 5, 2005, $\mathrm{H}_{2} \mathrm{~S}$ was released from a feedstock pit at a biogas plant at Rhadereistedt, Zeven, Germany. During unloading of a tanker truck, large quantities of $\mathrm{H}_{2} \mathrm{~S}$ were released which lead to instant knockdown of all four persons in the building, who eventually died. Mouth froth was observed on all four victims. Another truck driver collapsed near the exit gate, he was seriously injured but survived. There were ten casualties amongst the fire and rescue services [9].

The substrate responsible was pig intestinal mucosa waste, which had been processed at a pharmaceutical site for extraction of heparine, an anticoagulant. The substrate had a "high sulfide content" and was slightly alkaline with a $\mathrm{pH}$ of 8.5. The German investigators speculated that the sulfide content was a result of biochemical degradation [26]. We note that this is similar to our hypothesis for generation of $\mathrm{H}_{2} \mathrm{~S}$ in food waste: protein degradation and the action of sulfate reducing bacteria. We further comment, that during industrial heparine extraction, intestinal mucosa is often preserved using an oxygen scavenger such as sodium hydrogen sulfite [27], some of which may have been reduced and contributed to the high sulfide content. The German investigation stated that whey concentrate and animal by-products had been offloaded into the pit the day before. Overnight, the $\mathrm{pH}$ of the pit "had lowered". We consider the process to be microbial acidification. A rapid release of large amounts of hydrogen sulfide took place when the slightly alkaline and warm $\left(60^{\circ} \mathrm{C}\right)$ mucosa substrate was dumped into the pit's much larger volume of slightly acidic material with the stirrer turned on.

The German coverage emphasizes that the lid of the feedstock pit was stuck in the open position due to a mechanical breakdown, which made the pit's local exhaust ventilation ineffective. At Hashøj, the lid was also open (by intention), which short-circuited the air flow and made the local exhaust ventilation ineffective. We question the significance of the open lid however. The ventilation systems appear to be designed for odor control, not for handling of unanticipated sudden releases of large quantities of toxic gases. 
The key difference between the two cases is the $\mathrm{pH}$ of the offloaded substrate. At Rhadereistedt, the $\mathrm{pH}$ was slightly alkaline and able to keep $\mathrm{H}_{2} \mathrm{~S}$ in solution. At Hashøj, the $\mathrm{pH}$ was acidic, and because of openings in the tank, we believe that any gases accumulated would have vented away during the road voyage. As opposed to Rhadereistedt, we cannot offer a compelling mechanism for the sudden gas release at Hashøj.

On Feb 19, 2011, at Žd'ár nad Sázavou, Czech Republic, three persons were exposed to a release of biogas. Two were taken to hospital. All victims survived. Firefighters later measured high concentrations of carbon dioxide in the area. On Nov 3, 2014, at the Sabiedribas Marupe biogas facility near Riga, Latvia, a biogas leak killed two workers. A would-be rescuer also collapsed but survived. The very limited information available in e.g. news outlets $[6,28,29]$ does not permit a discussion of the potential relevance to the Hashøj case.

\subsection{Limited information available}

Scarcity of data prevents us from providing a more detailed discussion. Using the Danish equivalent of a Freedom of Information Act, documents were sought from the environmental and workplace authorities and the Police. The two authorities responded promptly. The police declined, possibly because of resistance from the Plant owner. An appeal procedure eventually released the documents, but with vital information such as photos of the pit and the lid censored out. The reason for the secrecy is difficult to understand. The workplace authority and Police documents have been of limited value anyway due to the superficial nature of the investigations.

Only the municipal environmental authority addressed this accident in a competent manner, carrying out some basic data collection activities to which it applied critical analysis and logical reasoning founded in chemical and toxicological insights. When asked why they had not undertaken a more detailed analysis of e.g. the food waste and pit contents, they argued (correctly) that their mandate was limited: this was essentially a workplace accident with limited or no potential to cause environmental harm outside the premises of the biogas plant.

Vendors of food waste shredder recycling systems have not been particularly forthcoming and have not returned requests for information. Hospital kitchens have been decidedly unhelpful.

\subsection{Limited information sharing}

The Hashøj incident was debated amongst site managers and board representatives at a closed meeting on Oct 6, 2015, organised by the Danish Society of Biogas Plants [30]. Of more than 162 biogas plants operating at the time, only 25 participated. The authors are not aware of any official actions undertaken by the workplace authority, or other authorities.

\subsection{Limited sustainability}

Each year, the World Energy Council benchmarks the sustainability of the world's national energy systems. In 2016, Denmark not only attained a triple-A score, it also topped the World Sustainability Index at rank \#1 [31]. It is morally problematic, if sustainable climate change interventions, which receive huge public subsidies, are pursued so narrow-mindedly that sight is lost of the environment of the workers. 
Utmost care should be taken to avoid media shifting [32] - that the resolution of a problem within one domain, the environmental, creates a new problem in another, the workplace safety domain. 


\section{Conclusion}

The Hashøj case offers the following general accident prevention lessons for biogas units:

- Food waste slurry from shredder systems may give off toxic hydrogen sulfide gas in quantities that produce dangerous and potentially fatal concentrations. Potentially, the hazard may exist in the entire food waste logistics chain. More research is necessary.

- The slurry may have properties similar to dangerous substances but it is not classified or labelled as such.

- For odor emission control, the feedstock pit is often located inside a building, which amplifies the consequences of a gas release. The gas release may overwhelm ventilation systems.

- Local exhaust ventilation should be so designed that it is still effective when the lid is open, which anyway is the normal position when truck drivers are nearby.

- In high concentrations, $\mathrm{H}_{2} \mathrm{~S}$ paralyses the olfactory system and gives no warning to operators. There should be a fixed gas detection system with audible and visible alarm, and possibly also a signal to open gates for maximum natural ventilation

- The gas hazard and the staff's proper emergency response must be communicated widely. In the Hashøj case, emotional stress and a heroic urge to "do something" not only put the would-be rescuers at extreme risk, but also degraded their capacity to perceive obvious danger. Even after having collapsed themselves, been extracted and recovered, they re-entered the building amazingly still without realizing the gas danger.

The actions of the fire and rescues services did more harm than good. Their misleading reporting of the presence of $\mathrm{NO}_{\mathrm{X}}$ fumes not only misinformed hospital emergency room staff, but also derailed the accident investigation efforts and corrupted the media coverage.

The workplace authority did nothing to investigate this accident. The busy inspectors spent a few hours at the site, issued a couple of orders and then left. The police carried out a crime scene investigation, found no evidence of wrongdoing and closed the case. As a result, we cannot state with certainty, which gases were released, where (container or pit) they were released, how they were released or why they were generated in large quantities. This limits accident prevention efforts. While general risk mitigation measures (sensors, ventilation, etc.) can be devised, primary preventive measures cannot.

The biogas sector seems incapable of carrying out proper accident investigations and dissemination of lessons learned. Most facilities are run by farmers with little or no training in the operation of 
process equipment containing flammable and poisonous gases. Change of mentality is required if this sector is to meet a common sense definition of sustainability that also includes the workplace.

We are of the opinion that the Hashøj accident provides important lessons relevant for the general biogas industry and we sincerely hope that this communication will contribute to an improved appreciation of the hazards of handling substrates, food waste in particular. 


\section{Conflicts of interest}

None of the authors has conflicts of interest to declare. 


\section{Acknowledgements}

We would like to extend our gratitude to the interviewees and to the municipal environmental authority, who made this article possible. Professor Jes la Cour Jansen kindly commented on an early version of the paper. This article has been produced as a voluntary effort and has not received any funding. Opinions expressed are those of the authors, not their employers' or organizations'. 


\section{$9 \quad$ References}

[1] J. Puertas, 2009-2012 Triennum Work Report. Renewable Gas - The Sustainable Energy Solution., Kuala Lumpur, Malaysia, 2012.

[2] Regeringen, Grøn Vækst (Green Growth), Regeringen (The Danish Government), Copenhagen, Denmark, 2009.

[3] Danish Energy Authority, Biogas i Danmark - status, barrierer og perspektiver (Biogas in Denmark - status, barriers and perspectives), København, Denmark; 2014.

http://www.ens.dk/sites/ens.dk/files/dokumenter/publikationer/downloads/biogas_i_danm ark_-_analyse_2014_web.pdf.

[4] Danish Energy Authority, Biogas i Danmark - status, barrierer og perspektiver (Biogas in Denmark - status, barriers and perspectives), Energistyrelsen (Danish Energy Agency)., København, Denmark;, 2014.

http://www.ens.dk/sites/ens.dk/files/dokumenter/publikationer/downloads/biogas_i_danm ark_-_analyse_2014_web.pdf.

[5] Regeringen, Danmark uden affald. Genanvend mere - forbrænd mindre. (Denmark without waste. Recycle more - incinerate less.), Regeringen (The Danish Government), København, Denmark; 2013.

[6] P. Trávníček, L. Kotek, Risks associated with the production of biogas in Europe, Process Saf. Prog. 34 (2015) 172-178. doi:10.1002/prs.11734.

[7] T.P.T. Pham, R. Kaushik, G.K. Parshetti, R. Mahmood, R. Balasubramanian, Food wasteto-energy conversion technologies: Current status and future directions, Waste Manag. 38 (2015) 399-408. doi:10.1016/j.wasman.2014.12.004.

[8] S.K. Karmee, Liquid biofuels from food waste: Current trends, prospect and limitation, Renew. Sustain. Energy Rev. 53 (2016) 945-953. doi:10.1016/j.rser.2015.09.041.

[9] M. Will, Unfall in der Betriebshalle der Biogasanlage in Rhadereistedt; Vier Tote - ein Schwerverletzter - zehn verletzte Feuerwehrleute (in German). [Accident at biogas plant in Rhadereistedt. Four dead - one seriously injured - ten injured firemen], Fachausschuss "Brandschutzerziehung Und Brand. Im Landesfeuerwehrverband Nord. e.V. (2005). http://www.sicherheitserziehung-nrw.de/uploads/media/Unfall in der_Biogasanlage2005.pdf(Retrieved 14 April 2013).

[10] F.H. Hedlund, Biomass Accident Investigations - Missed Opportunities for Learning and Accident Prevention, in: L. Ek, H. Ehrnrooth, N. Scarlat, A. Grassi, P. Helm (Eds.), Pap. 25th Eur. Biomass Conf. 12-15 June 2017, Stock. Sweden. Setting Course a Biobased Econ., ETA-Florence Renewable Energies, 2017: pp. 1804-1814. doi:10.5071/25thEUBCE2017-4AV.2.45.

[11] V. Casson Moreno, D. Guglielmi, V. Cozzani, Identification of critical safety barriers in biogas facilities, Reliab. Eng. Syst. Saf. 169 (2018) 81-94.

doi:10.1016/j.ress.2017.07.013. 
[12] V.C. Moreno, V. Cozzani, Major accident hazard in bioenergy production, J. Loss Prev. Process Ind. 35 (2015) 135-144. doi:10.1016/j.jlp.2015.04.004.

[13] P. Trávníček, L. Kotek, P. Junga, T. Vítěz, K. Drápela, J. Chovanec, Quantitative analyses of biogas plant accidents in Europe, Quantitative analyses of biogas plant accidents in Europe, Renew. Energy. 122 (2018) 89-97. doi:10.1016/j.renene.2018.01.077.

[14] L. Oesterhelweg, K. Püschel, "Death may come on like a stroke of lightening ...": Phenomenological and morphological aspects of fatalities caused by manure gas, Int. J. Legal Med. 122 (2008) 101-107. doi:10.1007/s00414-007-0172-8.

[15] J. Strickland, A. Cummings, J.A. Spinnato, J.J. Liccione, G.L. Foureman, Toxicological review of hydrogen sulfide (CAS No. 7783-06-4), U.S. Environmental Protection Agency, Washington, DC, 2003. http://cfpub.epa.gov/ncea/iris/iris_documents/documents/toxreviews/0061tr.pdf.

[16] M. Kleinfeld, C. Giel, A. Rosso, Acute Hydrogen Sulfide Intoxication; An Unusual Source of Exposure, Ind. Med. Surg. 33 (1964) 656-660.

[17] L.C. McCabe, G.D. Clayton, Air pollution by hydrogen sulfide in Poza-Rica, Mexico - An evaluation of the incident of Nov 24, 1950, Ama Arch. Ind. Hyg. Occup. Med. 6 (1952) 199-213.

[18] F.H. Hedlund, The extreme carbon dioxide outburst at the Menzengraben potash mine 7 July 1953, Saf. Sci. 50 (2012) 537-553. doi:10.1016/j.ssci.2011.10.004.

[19] NIOSH, NIOSH criteria for a recommended standard for occupational exposure to oxides of nitrogen (nitrogen dioxide and nitric oxide), Washington, DC., 1976.

[20] B. Weinberger, D.L. Laskin, D.E. Heck, J.D. Laskin, The Toxicology of Inhaled Nitric Oxide, Toxicol. Sci. 59 (2001) 5-16. doi:http://dx.doi.org/10.1093/toxsci/59.1.5.

[21] N. Kamangar, Nitrogen Dioxide Toxicity, Medscape. (2017) 1-3. http://emedicine.medscape.com/article/302133-overview (accessed January 27, 2017).

[22] R. Hajela, D.T. Janigan, P.L. Landrigan, S.F. Boudreau, S. Sebastian, Fatal pulmonary edema due to nitric acid fume inhalation in three pulp-mill workers, Chest. 97 (1990) 487-489. doi:10.1378/chest.97.2.487.

[23] S. Kusnetz, M.K. Hutchison, A Guide to the Work-relatedness of Disease, 1979. https://www.cdc.gov/niosh/pdfs/79-116-a.pdf.

[24] J. Moestedt, S.N. Paledal, A. Schnurer, The effect of substrate and operational parameters on the abundance of sulphate-reducing bacteria in industrial anaerobic biogas digesters, Bioresour. Technol. 132 (2013) 327-332. doi:10.1016/j.biortech.2013.01.043.

[25] G. Muyzer, A.J.M. Stams, The ecology and biotechnology of sulphate-reducing bacteria, Nat. Rev. Microbiol. 6 (2008) 441-454. doi:10.1038/nrmicro1892.

[26] Umweltbundesamt, Schwefelwasserstoff-Freisetzung in einer Biogasanlage (in German) [Release of hydrogen sulfide at biogas plant], Umweltbundesamt, 2005.

[27] J.-Y. van der Meer, E. Kellenbach, L.J. van den Bos, From Farm to Pharma: An Overview of Industrial Heparin Manufacturing Methods, Molecules. 22 (2017). doi:10.3390/molecules22061025.

[28] Enviroweb, $Z$ bioplynové stanice unikal metan, třri lidé se nadýchali (In Czech) [Escape of methane at biogas plant, three persons exposed], Enviroweb S.R.O ISSN 8036686. (2011). http://www.enviweb.cz/clanek/bioplynky/85430/ (accessed February 7, 2017).

[29] Baltic, Two dead in accident at biogas cogeneration station outside Riga, Balt. Course. (2014). http://www.balticcourse.com/eng/energy/?doc=98459\&gtnjs=1 (Retrieved Nov 13, 2016).

[30] B.S. Nielsen, Aktivt formandsmøde i Biogasforeningen (Active chairmen's meeting the biogas association), Bioenergimagasinet. (2015) 12-13.

[31] World Energy Council, World Energy Trilemma, 2016. Benchmarking the sustainability 
of national energy systems, London, U.K., 2016. http://www.worldenergy.org/wpcontent/uploads/2016/10/ Full-report_Energy-Trilemma-Index-2016.pdf (retrieved 19 Oct 2016).

[32] N.A. Ashford, Industrial safety: the neglected issue in industrial ecology, J. Clean. Prod. 5 (1997) 115-121. doi:http://dx.doi.org/10.1016/S0959-6526(97)00024-3. 